\title{
STABILITY OF THE NEW ALLUVIAL FAN OF EL PARTIDO STREAM, LOCATED IN THE EASTERN SIDE OF EL ROCÍO VILLAGE IN THE DOÑANA NATIONAL PARK (SPAIN), AFTER THE ACTIONS CARRIED OUT TO RESTORE ITS HYDROLOGICAL REGIME
}

\author{
J.A. MINTEGUI AGUIRRE, J.C. ROBREDO SÁNCHEZ, \\ C. DE GONZALO ARANOA \& P. HUELIN RUEDA \\ Departamento de Ingeniería Forestal, Escuela Técnica Superior de Ingenieros de Montes, \\ Universidad Politécnica de Madrid, Spain.
}

\begin{abstract}
We present, first of fall, a recall of the formation of a new alluvial fan at El Partido stream between 1982 and 2006, located in the eastern side of El Rocío village, over the Doñana National Park Marshes, as a result of the channelization of the mentioned stream with crop purposes in 1981. The settlement of the new alluvial fan, over an area of special protection, and the concerns linked to its expansion and growth, hindering the drainage of the urbanized area of El Rocío village after flood events, caused a strong impact. The analysis of the situation drove to the conclusion that the most suitable measure to stabilize the new alluvial fan was to restore the functionality of the former alluvial fan located upstream the study area. The restoration works were executed in 2006 and from the year 2007 the monitoring of its behavior in several flood events that occurred in the stream has been carried out. This paper summarizes the followed restoration scheme of the former alluvial fan and describes the main monitoring tasks, especially during the last 2 years focused specifically in the neighborhood of El Rocío village. To conclude, a description of the recent flood behavior along the final reach of the stream, as a result of the restoring works and its impact on the current stability of the new alluvial fan has been provided. Keywords: flood defense, hydrological correction, stabilization of an alluvial fan, torrential event.
\end{abstract}

\section{INTRODUCTION}

The Arroyo del Partido is a stream with a gentle slope $\left(<0.002 \mathrm{~m} \cdot \mathrm{m}^{-1}\right)$ draining into El Rocío Marsh in the Doñana National Park (DNP) in southwestern Spain. El Partido watershed, with an area of $307.67 \mathrm{~km}^{2}$ and a slope of $4.3 \%$ on average, is located between $6^{\circ} 25^{\prime}$ and $6^{\circ} 41^{\prime} \mathrm{W}$ Longitude and between $37^{\circ} 22^{\prime}$ and $37^{\circ} 7.5^{\prime} \mathrm{N}$ Latitude. Its main channel has a length of $39 \mathrm{~km}$. The morphological features and hydrological regime of the stream show a strong torrential pattern: streamflow may be increased by 200 times when heavy rainfalls affect the catchment area. In fact, prior to 1981 the Arroyo del Partido presented the classical torrential scheme: catchment area, gorge, alluvial fan, and discharge channel. Then, during major flood events, surplus flow was expanded over the former alluvial fan, before reaching the DNP marshes. Thus, the streamflow was laminated, suffering a head loss and thus producing the subsequent sediments deposition. In this way, the flow spilled into the DNP marshes in a near-steady uniform regime, devoid of sediments, throughout two different drainage channels. The Almonte-Marismas irrigation plan transformed this area for crop purposes in 1981, channeling the last $7 \mathrm{~km}$ of the stream before the marshes. This transformation constrained the floods into the channel, and thus the former alluvial fan behaved as an extension of the original gorge. This fact caused the formation of a new alluvial fan at the end of the channelization, within the DNP marshes bounds, as a result of channel bed degradation due to the bed shear stress increase. Moreover, this new situation also triggered retrogressive erosion processes. In July 2003, the new alluvial fan surface was evaluated in $4.31 \mathrm{~km}^{2}$ with a volume of $4.48 \times 10^{6} \mathrm{~m}^{3}$ [1-6]. 
Accordingly, in order to prevent the growth of the new fan over the DNP marshes and the flooding and aggradation of the eastern neighborhood of El Rocío village, found at the edge of the DNP marshes, it was proposed to restore the original hydraulic and hydrological regime of El Partido stream. With this purpose it was planned: 1) to build up a check dam in a stream section at the original sedimentation fan apex, about $6 \mathrm{~km}$ upstream of El Partido stream mouth, in order to control retrogressive erosion processes and 2) to allow the flood expansion, during major rainfall events, downstream the check dam section to recover a part of its former floodplain. The proposed works were executed in 2006, constituting the Action Number 3 (A3) of a major project on Water Regeneration of the DNP Marshes, called Doñana 2005 Project. Given the great environmental impact of the project, an Executive Committee and a Scientific Committee for its monitoring was created [7].

A main aspect to be noted is that prior to the stream channelization, El Partido and the Parrilla streams had their own drainage channels, and their catchment areas were split (Fig. 1); but both streams shared a single alluvial fan, and therefore they naturally interchanged their streamflow during major flood events. This effect permitted the Parrilla stream (in this area the name Parrilla stream changes to Cañada del Pinar stream) to behave as a drainage channel of the El Partido catchment area. In 1981, the channelization connected the Parrilla stream to El Partido channel; thereby preventing the Parrilla stream from working as a drainage channel.

Another main aspect taken into account for monitoring was the continuity of El Partido stream after crossing the sedimentation fan from north to south and becoming a caño, namely Caño Ajolí, before flowing into the DNP marshes near the eastern border of El Rocío (in this area a caño is known as the low flow channel or drainage). After the channelization of El Partido stream, the flood flows dragged such amount of sediments that the Caño Ajolí completely disappeared due to aggradation processes. Thereafter, El Partido set out a new path, over the new fan, westwards and closer to El Rocío village.

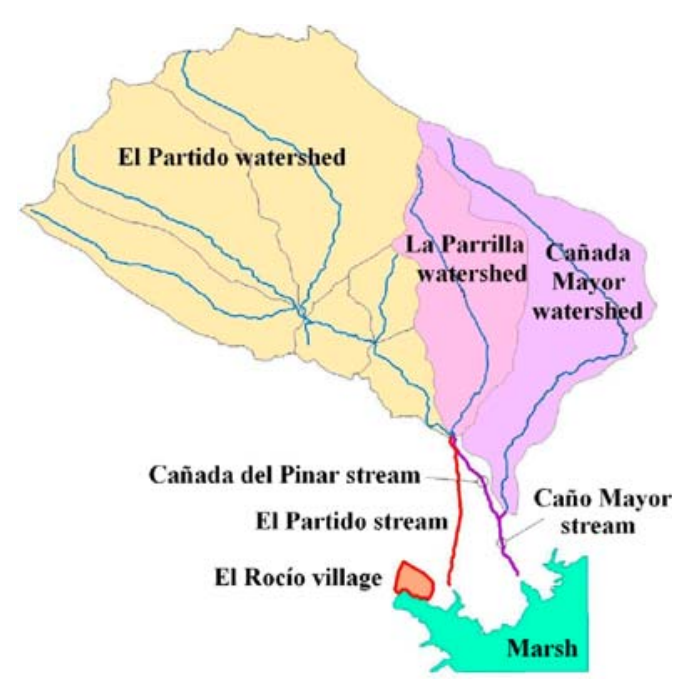

Figure 1: Watersheds and drainage networks of El Partido, Parrilla-Cañada del Pinar, and Cañada Mayor streams. In flood events the last reaches of the streams that interchange the flow permits the Cañada del Pinar stream to perform as a drainage channel of El Partido alluvial fan. 


\section{OBJECTIVES}

This paper describes: a) the actions carried out under the A3 of the Doñana 2005 Project in the summer of 2006, and their spatial location over the former alluvial fan of El Partido; b) the A3 monitoring over the 2006-10 period; c) the adjustments made to the initial design of the works in order to improve the behavior of the flood control system (FCS) against the actual torrential stream regime, to finally ensure a medium- and long-term hydraulic and hydrological restoration; and finally d) the performance of the FCS during the 2009-10 winter period is analyzed.

\section{METHODOLOGY}

Since the A3 attempted to restore the previous hydrological and hydraulic performance of a large part of the former alluvial fan surface by means of a FCS, the adopted monitoring methodology addresses the following tasks: 1) the objectives and expected performance of the works and regulations implemented with the A3 are explained. After the A3 execution in the summer of 2006, all the essential elements of the project (drainage channels, check dams, flood areas, levees) were geographically repositioned as detailed in Section 3.1. 2) During the period 2006-08, the behavior of the executed works according to the initial project design was observed, which permitted the proposal, at the end of such period, of the necessary adjustments of the works in order to redirect the A3 to its initial goals. 3) After the adjustments implemented in the autumn of 2008, the performance of the FCS in the two major flood events occurred in the hydrological year 2008-09 was analyzed, which showed the effectiveness of the adjustments and the convenience of maintaining them permanently. This aspect has been confirmed by analyzing the actual behavior and the simulation runs with HEC-HMS (Hydrologic Engineering Center-Hydrologic Modeling System) [8] of the FCS in the first six major flood events that occurred during the hydrological year 2009-10. 4) To conclude, a description of the current operation of El Partido FCS, established with the A3, and adjusted to the actual conditions of the stream regime, is provided, assisted with the hydraulic model HEC-RAS (Hydrologic Engineering Center-River Analysis System) [9].

The topographical survey was conducted with a topographic level, a total station, and a differential global positioning system (DGPS). The measurements surveyed with the DGPS, which are referred to the WGS84 ellipsoid, were transformed into orthometric elevations using an undulation map prepared for this purpose within a larger project in the DNP marshes [10].

\subsection{Initial design of the works and regulations adopted under the A3 of the Doñana 2005 Project}

The operations implemented by the A3 in order to achieve the FCS aims (which monitoring has presented in this paper), consisted of: a) the construction of a check dam on El Partido channel in a section at the beginning of the former alluvial fan (Check Dam 1 or CD1), b) the construction of a second check dam on the Cañada del Pinar stream (Check Dam 2 or CD2), and c) to enable a flooding surface, available for flood, lamination, and sediments deposition, placed between both streams at the left overbank of El Partido stream, from the CD1 section and downstream to the DNP direction. In this way, a large part of the original floodplain was restored. Due to socio-economic constraints, the crops on the right overbank of El Partido stream (and the protection levee) remained in place. The drainage of this last area was redirected to an existing caño, known as Caño Marin, for which a drain was disposed straightforward to the marsh. Further sedimentation processes at the surroundings of El 
Rocío, caused by the flood events of El Partido, modified this design and nowadays both channels discharge together to the marsh.

The aim of the CD1 and CD2 is to trigger the flooding of the flood-lamination-sedimentation area. For this reason, this paper focuses mainly on the discharge sections of both check dams. Besides, these two elements of the FCS were the only being subjected to further adjustments. The specific mission of each check dam and its main features at the time of execution (2006) are briefly described below.

\subsubsection{Check dam 1}

The specific objectives of the CD1 are: a) controlling retrogressive erosion processes upstream its location and b) distributing the streamflow between the Arroyo del Partido channel and the flood-lamination-sedimentation area. The CD1 crest height is $2.6 \mathrm{~m}$ above the current streambed. Originally, the frontal spillway (which is an overflow spillway or broad-crested weir) was $2.0 \mathrm{~m}$ high, $70.0 \mathrm{~m}$ long, and $2.0 \mathrm{~m}$ wide, situated at an average crest height of $16.7 \mathrm{~m}$ a.s.1. 31 weep holes, with $0.3 \mathrm{~m}$ in diameter, crossed the structure from the upstream to the downstream face, draining the water volume stored behind the structure. The weep holes were arranged in two rows (of 15 weep holes each) and a single bottom drain (Fig. 2). The lateral overflow spillway was placed immediately upstream of the structure along the left riverbank, coated with a rocky breakwater and a cyclopean concrete lining in order to prevent erosions when the diverged flow passes over it and comes into the flood-lamination-sedimentation area. The lateral spillway has a length of $140 \mathrm{~m}$ and its crest altitude ranges between 16.70 and $16.77 \mathrm{~m}$ a.s.l. due to its roughness.

\subsubsection{Check dam 2}

The CD2 mission is to regulate the flood level in the floodplain, ensuring a subcritical flow regime within this latter. The $\mathrm{CD} 2$ is $1.5 \mathrm{~m}$ high at the crest and was built immediately upstream of the bridge over the Cañada del Pinar stream, on the road connecting El Rocío and Villamanrique (Fig. 3). The overflow spillway is $29.5 \mathrm{~m}$ long, $2.0 \mathrm{~m}$ high, and $3.0 \mathrm{~m}$ wide,
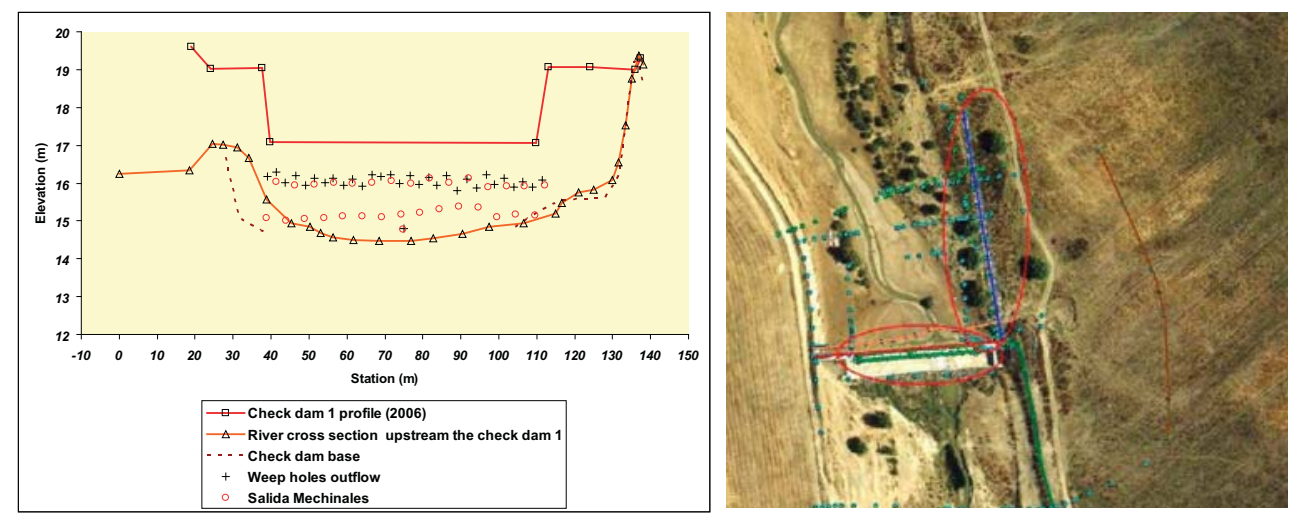

Figure 2: Left: Elevation view of the CD1 over El Partido stream in 2006. Right: Aerial photograph (2008) of the CD1 and plan view. The frontal spillway is highlighted with the red line and horizontal ellipse and the lateral spillway is highlighted with the blue line and vertical ellipse. 

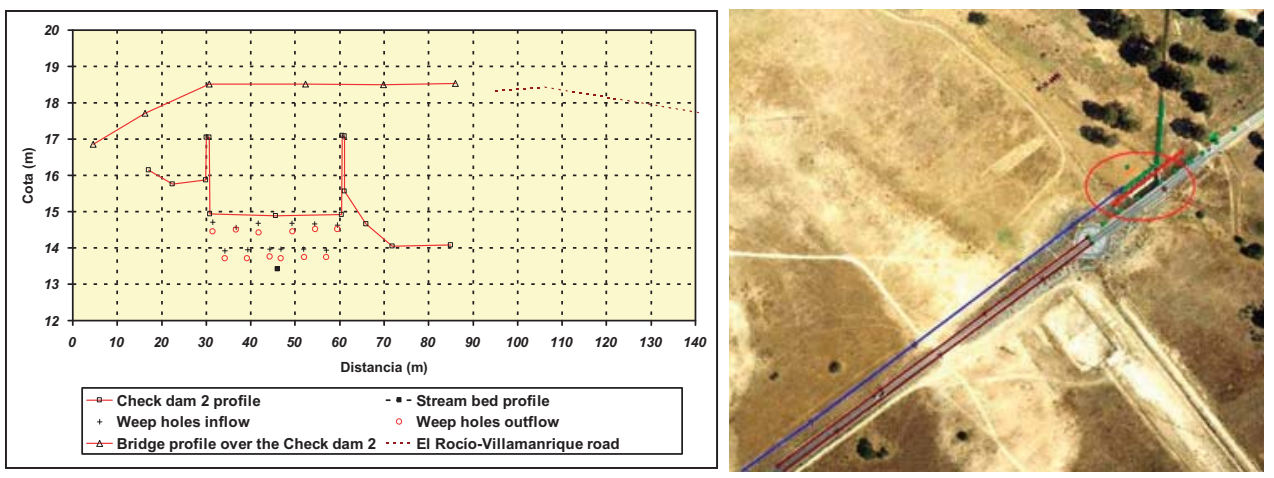

Figure 3: Left: Elevation view of the CD2 over the Cañada del Pinar stream in 2006. Right: Aerial photograph (2008) of the CD1 and plan view. Its spillway is highlighted with the red ellipse.

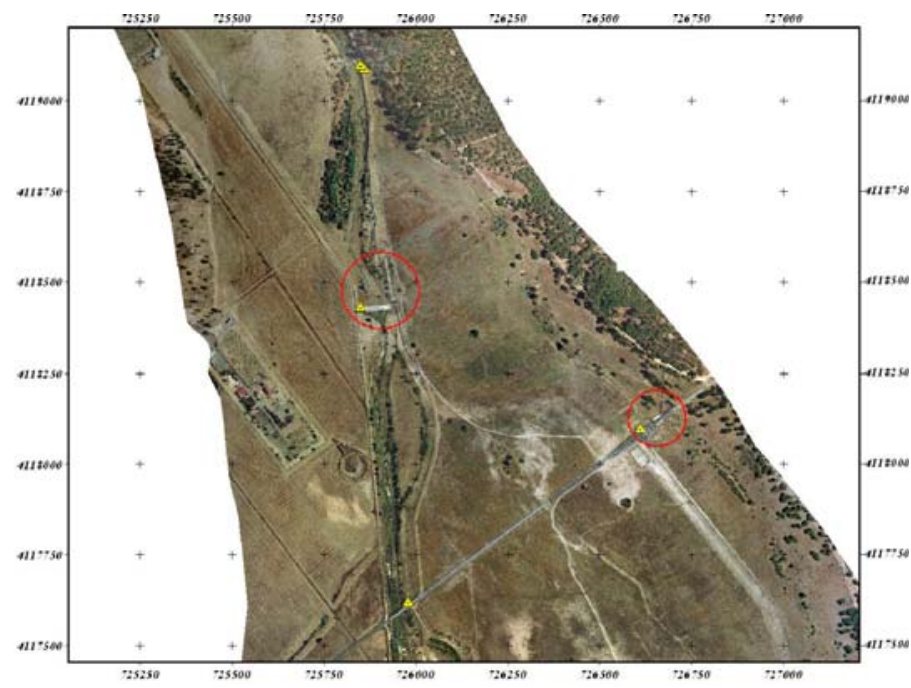

Figure 4: Aerial photograph (2008) showing the northern section of the flood-laminationsedimentation area recovered with the A3. El Partido stream drains along the left side of the image and the Cañada del Pinar stream drains along the right side.

with an average crest height of $14.62 \mathrm{~m}$ a.s.l. The structure is crossed by 12 weep holes, with $0.3 \mathrm{~m}$ in diameter, draining the volume stored behind the check dam, arranged in two rows (of six weep holes each).

\subsubsection{Flood-lamination-sedimentation area. Concerns about its behavior in major flood} events during the A3 drafting

The flood-lamination-sedimentation plain is composed of two different areas. In Fig. 4, the northern section is shown, with an area of 57 ha, which is the first part being flooded. For this reason a geometric leveling of its perimeter was performed on 19 July 2003. In the same 
figure, CD1 and CD2 are marked with red circles. The southern boundary of this first floodplain is defined by a paved road connecting El Rocío and Villamanrique villages, crossing the floodplain from west to east. The mentioned stretch of the road (between the two bridges over the two streams in study) operates as a discharge threshold in extreme flood events, so that a geometric leveling of it was performed on 18 October 2008. The southern floodplain (gathered only partially in Fig. 4) is located downstream of the paved road, having an area of 227 ha and extends up to the end of the former sedimentation fan, which could be demarcated by means of aerial photographs taken before channelization.

The flood-lamination-sedimentation area presents a gentle slope eastward; therefore, the flood level is directed toward the Cañada del Pinar stream. During the drafting of the A3 this fact was cause of concern because of the uncertainty of the geomorphic behavior of the ground surface during the passage of flood flows from the lateral spillway of the CD1. Therefore, in the initial design of the FCS a conservative flow distribution was adopted for the CD1. Using a design flow of a flood having hundred-year recurrence interval (estimated in 358 $\mathrm{m}^{3} \cdot \mathrm{s}^{-1}$ ), the flow would be distributed as follows: $40 \%$ would discharge through the frontal spillway and the weep holes, and the remaining $60 \%$ would flow through the lateral spillway.

\subsection{Area of the new alluvial fan of El Partido, outside El Rocío village}

The main place to be protected with the A3 lies downstream of the aforementioned area. It is the area where El Partido stream runs over the new sedimentation fan, in front of El Rocío village, as shown in Fig. 5. This new fan was formed in the period 1981-2006 by successive sand deposits transported by El Partido floods. Due to the streambed aggradation, the slope is directed westward, i.e. toward El Rocío village. Hence, in winter of the hydrological year

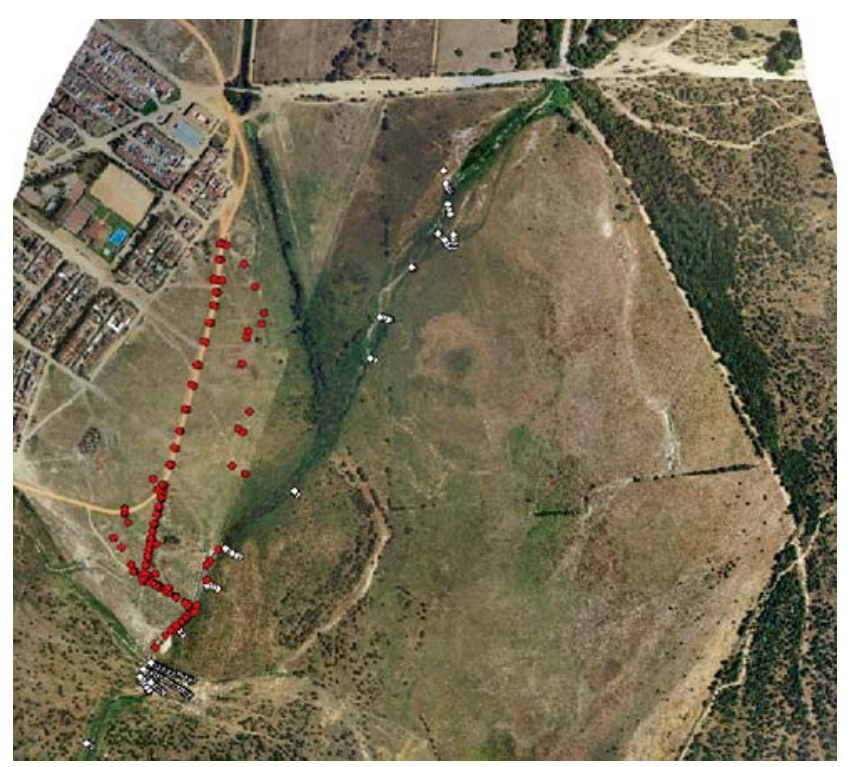

Figure 5: The routing of El Partido stream is marked with white dots from north to south over an aerial photograph of 2008. The dots in the image correspond to topographic survey made in 2007 (red) and 2008 (white). 
1997-98, a levee was built up, which can be distinguished at the left side of Fig. 5 (highlighted with red dots). In this same image, the J-shaped levee-end is appreciated in the left side of the image, encircling the urban area of El Rocío. At the top of the image is the Cañada Real, crossing from the Ford-Ajolí Bridge section (right) to the bridge over the Caño Marin stream (left). In the lower right corner of the image, the pumping station of El Rocio village is located, next to the DNP marsh boundary (southwest). In the center of the image, the confluence of the Caño Marín and El Partido streams can be distinguished.

The images in Fig. 6 show: a) on the left side an overview (from east to west) of the start of the new sedimentation fan of El Partido. The marsh and El Rocío village appear in the background; El Partido stream, crossed by the Cañada Real pathway, can be distinguished in the foreground. (2006); b) on the right side, a plan view of the Ford-Ajolí Bridge section from north to south (top to bottom) in an aerial photograph of 2008, with the Cañada Real pathway at the picture center (green dots highlighting topographical operations carried out in 2009). The stream branches out downstream the bridge; the non-operating channel appears on the right side and the new channel (operating since the winter 1997-98) on the left side.

In this section, the new alluvial fan apex of El Partido is located. Before the channelization, the Caño Ajolí flowed through the same section; the referred area was still a part of the marsh. The Ajolí Bridge is placed at this section, with the deck $2 \mathrm{~m}$ far from the streambed when constructed. After the channelization, the sandy sediments load produced the streambed aggradation, becoming nearer to the deck of the bridge, which was blown away several times by water and sand flows. Due to socio-cultural reasons this bridge has been rebuilt as many times as needed, but in 2000 a ford was built upstream next to the bridge ensuring the smooth flow of the traffic and protecting the existing bridge. This paper refers to this area as Ford-Ajolí Bridge section.

\subsection{Initial stage discharge curves at the CD1 and CD2}

Stage discharge curves were estimated at the CD1 and CD2, which determine the operation system of the FCS, and the flow allocation through the different spill elements, as originally designed in the project and as executed in the summer of 2006 (Fig. 7). Stage discharge
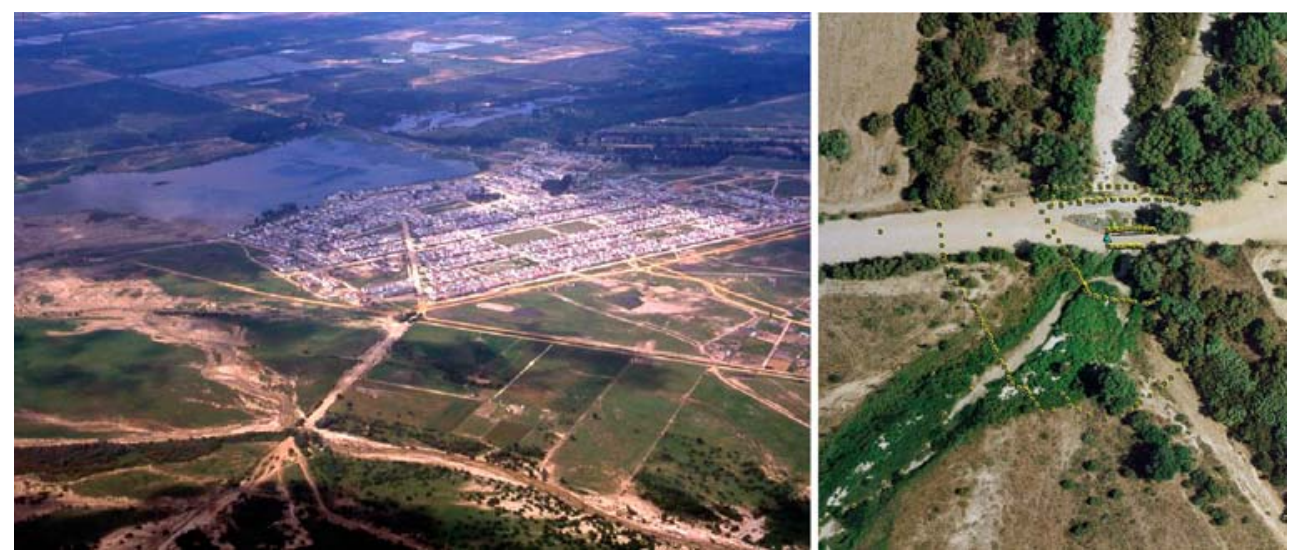

Figure 6: Left: Overview (from east to west) of the new sedimentation fan apex of El Partido (2006). Right: Plan view of the Ford-Ajolí Bridge section (2008) from north to south (top to bottom) with the Cañada Real road at the picture center. 

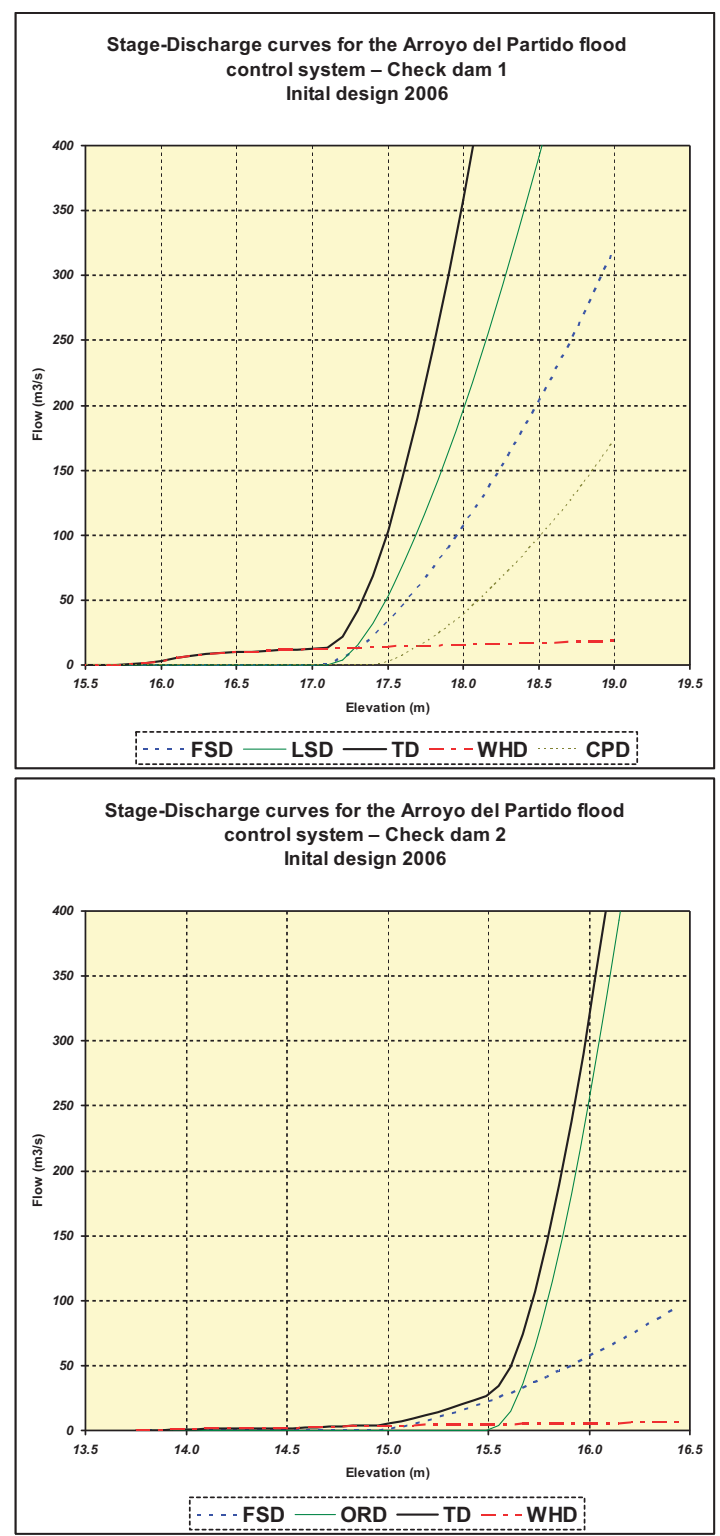

Figure 7: Top: Flow allocation $\left(\mathrm{m}^{3} \cdot \mathrm{s}^{-1}\right)$ at the CD1 among the different discharge sections with the initial design (2006). Bottom: The same allocation for the CD2. Frontal spillway discharge (FSD), lateral spillway discharge (LSD), total discharge (TD), weep holes discharge (WHD), Cañada del Pinar discharge (CPD), over road connecting El Rocío and Villamanrique discharge (ORD).

curves were established using the broad-crested weir and orifice equations, as typically used for hydraulic engineering works.

A concept that should be clarified, because it is used henceforth in this paper, is the flood flow associated with the FCS adopted under the A3 (FCS flood flow), which is set as the flood peak discharge through a hypothetical section grouping the discharge sections for both 
the CD1 and CD2. Hence, it would include both streamflows, in the situation prior to the lamination undergone with the FCS. In practice, this flow is identified with El Partido streamflow at the start of the former alluvial fan, represented in Fig. 4 by the upper central yellow triangle, because from that section the flow of both streams is interchanged during flood events. This effect is caused by the site geomorphology (it has been observed in the past), but has been accentuated by the backwater curve formed upstream of the CD1, since its construction in 2006.

\section{RESULTS AND DISCUSSION: MONITORING OF WORKS AND REGULATIONS ADOPTED UNDER THE A3}

4.1 The situation created by the major flood events of El Partido stream occurred between 2006 and 2008 after the execution of the A3 works, outside El Rocío village

In 2006, the construction of the CD1 limited El Partido streamflow that could reach to El Rocío to a value of about $100 \mathrm{~m}^{3} \cdot \mathrm{s}^{-1}$, which after the channelization, especially during the period 1995-98, was widely and repeatedly exceeded [2]. But the flow rate getting there was still high in major rainfall events, as happened in the flood on 2 February 2007, breaking the sanitation pipes going to the pumping station of El Rocío, and causing a sewage discharge to the marsh.

This flood event on 11 February 2007 warned of the need to undertake corrections of the original design of the discharge sections of the CD1 directed to El Partido stream, referred to in Section 3.1. As an immediate solution it was adopted: a) to repair the pipes and b) to extend the protective J-shaped embankment of El Rocío village toward the marsh, from the point of bending to the west. Figure 5 shows this extension that splits the streamflow of El Partido from the urban flow of El Rocío. The road connecting the mentioned protective embankment with the pumping station had a protective effect as well during the major flood events of the last hydrological year 2009-10. In compliance with the protocol fixed for the monitoring, the levees were topographically surveyed with a total station on 19 November 2007, and thus the heights of the protective levees were redefined. These operations are represented with red dots in Fig. 5.

Besides this event, with the monitoring of the adjacent area of El Rocío village and downstream of the Ford-Ajolí Bridge section, it was found that after the works execution, flood flow rates getting to this area had been decreased substantially, and the stream channel had begun to recover its primitive caño-type morphology, which had been lost as a result of sediments deposition in the period 1981-2006. However, the new caño channel was set on the sedimentary deposits carried by the flood events that occurred during this period (i.e. on the new alluvial fan) and not on the marsh bed that occurred in the past.

It was necessary to check the morphological recovery because it opened the possibility that flood flows would discharge at the flooded marsh area of the DNP with an uniform regime, with no sediments, thereby avoiding the possibility of altering the channel profiles with sedimentation processes, as it happened in the past before the channelization, when this place was drained by the Caño Ajolí [11]. In order to accomplish this objective, several crosssections of the last reach of the Arroyo del Partido, before the inlet into the flooded area, were surveyed in 2008 (white dots in the right image in Fig. 5). One of these sections surveyed on 17 October 2008 is shown in Fig. 8. In the graph on the left side the water stage corresponds to a flow rate of $0.30 \mathrm{~m}^{3} \cdot \mathrm{s}^{-1}$ running through the section, a situation in which the alluvial fan is stabilized. We estimated a maximum discharge capacity of this caño to be $4 \mathrm{~m}^{3} \cdot \mathrm{s}^{-1}$ (right graph in Fig. 8). This flow rate was taken into account to raise the A3 adjustments, particularly of the frontal overflow spillway profile at the CD1. 

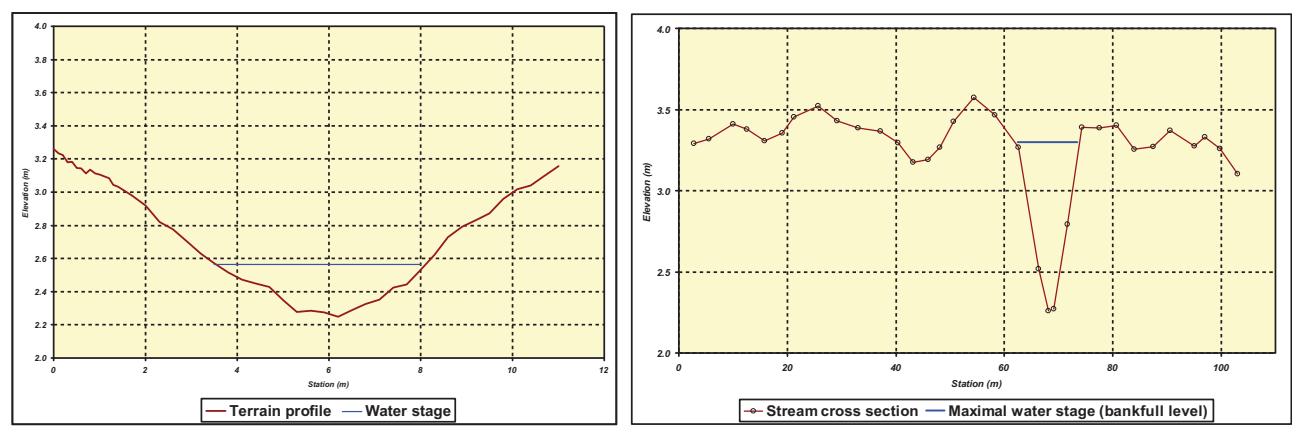

Figure 8: Left: Arroyo del Partido cross-section, on the last reach prior to the marsh inflow, gauged on 17 October 2008. Right: The same cross-section assuming a $4 \mathrm{~m}^{3} \cdot \mathrm{s}^{-1}$ flow (bankfull level).

As a first approach, it was estimated that this flow corresponded to the bank-full stage of the channel, i.e. the evacuation capacity related to the dominant channel forming flow, linked with its compensation slope [12]. The last flow rate determined by means of direct field survey was $0.0016 \mathrm{~m} \cdot \mathrm{m}^{-1}$. Accordingly, it was considered that for flow rates under $4 \mathrm{~m}^{3} \cdot \mathrm{s}^{-1}$, the sediment supply to the marsh remains beneath a moderated limit, since the flood remains into the drainage channel, and the sediment transport is essentially restricted to wash load. Above this value, the best option is to allow the flood expansion across both overbanks. For this purpose it is necessary to ensure enough space, moving away any protective embankment or levee to the outer limits of the predictable flood expansion. In this way, the shear stress is insufficient to erode the banks and sweep away sediments into the marsh.

\subsection{Adjustment of the initial design adopted for the A3}

The final solution to the problem described in Section 4.1 involves the reduction of the flow rates getting to the last reach of the Arroyo del Partido, so that the actual flow regime agrees with a caño-type flow regime. To say, the flow regime is balanced between the flow rate and the channel slope. Thereby major sediment flows to the marshes is prevented, and the flow expansion over the floodplain at the eastside of El Rocío village is ensured. In other words, to maintain very low water levels and flow speed rates, which is unable to mobilize sand from the streambed.

The adjustments of the discharge sections directed to El Partido channel at the CD1 involved: a) a modification of the initial frontal spill section (2006) by reducing its discharge surface; the new profile has a trapezoidal shape, cantered at the streambed, with a length of $20 \mathrm{~m}$ at the base and $24 \mathrm{~m}$ at the crest (keeping the original height, $2 \mathrm{~m}$ ); b) covering the weep holes with gravel, delaying the discharge through them during flood events. These corrections were operational in the autumn of 2008. The new stage-discharge curves of the FCS at the $\mathrm{CD} 1$, before and after the modifications are shown in Table 1.

4.3 Behavior of the A3 in the hydrological year 2008-09, after the adjustments made on the CD1

After the corrections were undertaken in the CD1 design, two major flood events occurred in El Partido stream: one on 1 February 2009 and the second on 5 February 2009 (Fig. 9, left plot). 
Table 1: Flow allocation for 20, 50, 100, 200, and $350 \mathrm{~m}^{3} \cdot \mathrm{s}^{-1}$ at the FCS through the different spill sections of the CD1 and through the Cañada del Pinar stream, due to the backwater effect of the structure.

\begin{tabular}{lccccc}
\hline & \multicolumn{5}{c}{ Flow distribution through different spill sections $\left(\mathrm{m}^{3} \cdot \mathrm{s}^{-1}\right)$} \\
\cline { 3 - 6 } CD1 scenario & $\begin{array}{c}\text { Flow rate } \\
\left(\mathrm{m}^{3} \cdot \mathrm{s}^{-1}\right)\end{array}$ & $\begin{array}{c}\text { Weep } \\
\text { holes }\end{array}$ & $\begin{array}{c}\text { Frontal } \\
\text { spillway }\end{array}$ & $\begin{array}{c}\text { Lateral } \\
\text { spillway }\end{array}$ & $\begin{array}{c}\text { Backwater in } \\
\text { Cañada del } \\
\text { Pinar }\end{array}$ \\
\hline Initial frontal & 20 & 12 & 1 & 7 & - \\
spillway (2006) & 50 & 15 & 10 & 25 & - \\
and operative & 100 & 15 & 20 & 65 & - \\
weep holes & 200 & 15 & 50 & 120 & 15 \\
& 350 & 15 & 90 & 210 & 35 \\
Modified frontal & 20 & - & 4 & 16 & - \\
spillway (2009) & 50 & - & 9 & 41 & - \\
and non-operative & 100 & - & 13 & 80 & 7 \\
weep holes* & 200 & - & 25 & 147 & 28 \\
& 350 & - & 40 & 253 & 57 \\
\hline
\end{tabular}

*The bottom drain remains operative with a discharge rate $>0.2 \mathrm{~m}^{3} \cdot \mathrm{s}^{-1}$.
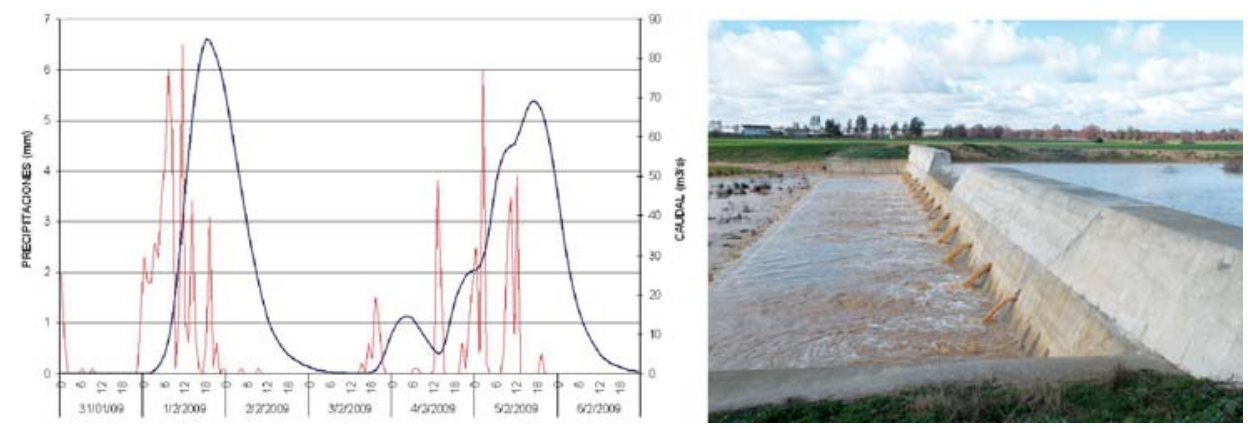

Figure 9: Left: Rain rate at the Bollullos meteorological station (placed approximately at the center of the Arroyo del Partido watershed) between 31 January and 5 February 2009 (red line). Peak flow estimated at the CD1 upstream face on 1 and 5 February 2009 (blue line). Right: Photograph of the CD1 at 13:00 h on 2 February 2009, after the flood of the previous evening.

The applied adjustments had an unexpected result. The flow pressure dragged the gravel blocking the weep holes through them, becoming last operative again, as shown in the photograph in Fig. 9, corresponding to 13:00 h (local time) on 2 February 2009. At that time, the flow hydrograph pointed out a flow rate of $15 \mathrm{~m}^{3} \cdot \mathrm{s}^{-1}$, which corresponded to a FCS flood flow passing through the CD1 weep holes, when fully operational (Table 1), as shown in the photograph in Fig. 9.

Regarding the flood on 5 February 2009, the photograph on the left side in Fig. 10 shows the discharge through the $\mathrm{CD} 1$ at 13:10 h (local time). At that time, the estimated flow rate in 

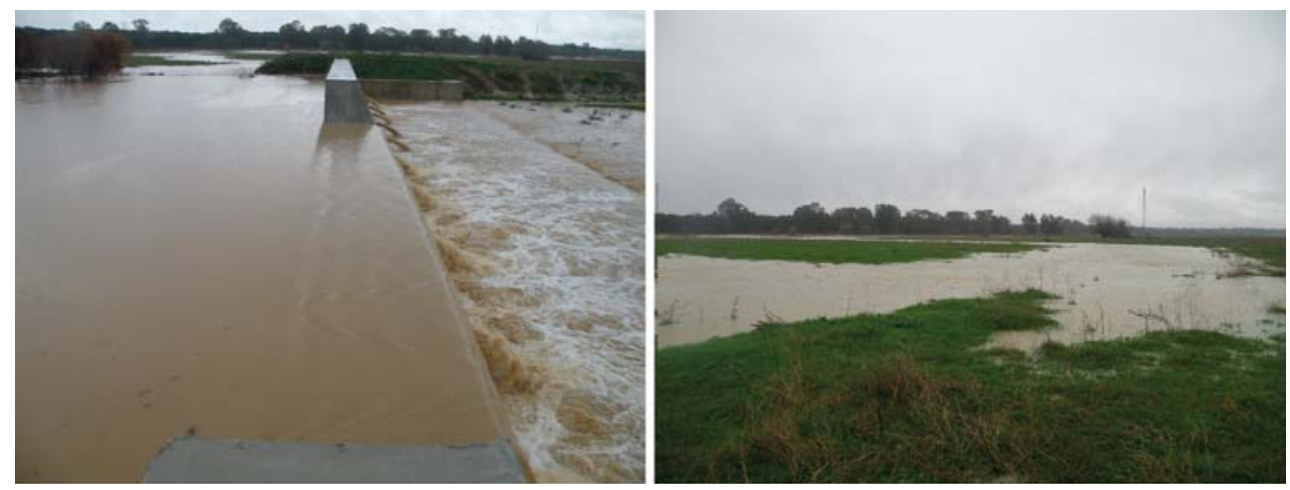

Figure 10: Flood in the Arroyo del Partido stream at 13:10 h local time on 5 February 2009. Left: Flow distribution at the CD1. Right: The flood flows downstream over the flood-lamination-sedimentation plain.

the flood hydrograph was $65 \mathrm{~m}^{3} \cdot \mathrm{s}^{-1}$ (Fig. 9, left image). In this case, $20 \mathrm{~m}^{3} \cdot \mathrm{s}^{-1}$ are discharged downstream directly to El Partido channel $\left(15 \mathrm{~m}^{3} \cdot \mathrm{s}^{-1}\right.$ through the weep holes and $5 \mathrm{~m}^{3} \cdot \mathrm{s}^{-1}$ through the frontal spillway) and the remaining $45 \mathrm{~m}^{3} \cdot \mathrm{s}^{-1}$ are diverged toward the floodlamination-sedimentation plain through the lateral spillway, to flow downstream the plain as shown in the right photograph in Fig. 10.

The flow rates for both flood events were estimated by means of simulation runs with the HEC-HMS hydrological model [8]. To estimate the FCS flood flow, the rainfall rate records of the Bollullos rain gauge station, at the watershed geographic center, were used. To do so, it was necessary to assume that the measurement represented the precipitation field covering the entire basin, since the basin was small, presented a moderate relief, and major rainfall events were considered. The basin curve number was established at $\mathrm{CN}=70$, and a condition III was applied for the simulation (due to the antecedent moisture of the basin). The time of concentration was calculated by the equation proposed by the USDA-SCS (1), which provided the best fit with respect to other expressions.

$$
t_{c}=0.071\left(\frac{L^{0.8}}{J^{0.25}}\right) \cdot\left(\frac{1000}{C N-9}\right)^{0.7}
$$

where $L$ is the length of the longest drainage path in $\mathrm{km}$ and $J$ is the average slope of the main channel from the watershed divide to the watershed outlet in $\mathrm{m} \mathrm{m}^{-1}$.

The obtained flow rates were compared with the photographs of the event at the CD1 and the flow rates of the theoretical FCS stage-discharge curves at the CD1. Although specific gauged values were not available, its credibility in the light of the time in which the photographs were taken seems to be significant.

The evaluation of the effects of these two flood events on the flood-lamination-sedimentation plain surface was more accurate. In addition to the photographs of the flood discharge (e.g. Fig. 10, right image), a topographical survey was carried out on 6 June 2009 to detail the geometry of several terrain profiles, because of their lower levels. Figure 11 shows three of these profiles, along with an outline of the FCS.

This survey verified that the flood flow was adapted to the micro-topography of the plain, defined by ancient flood drainage channels. Surveying operations were limited to the northern 


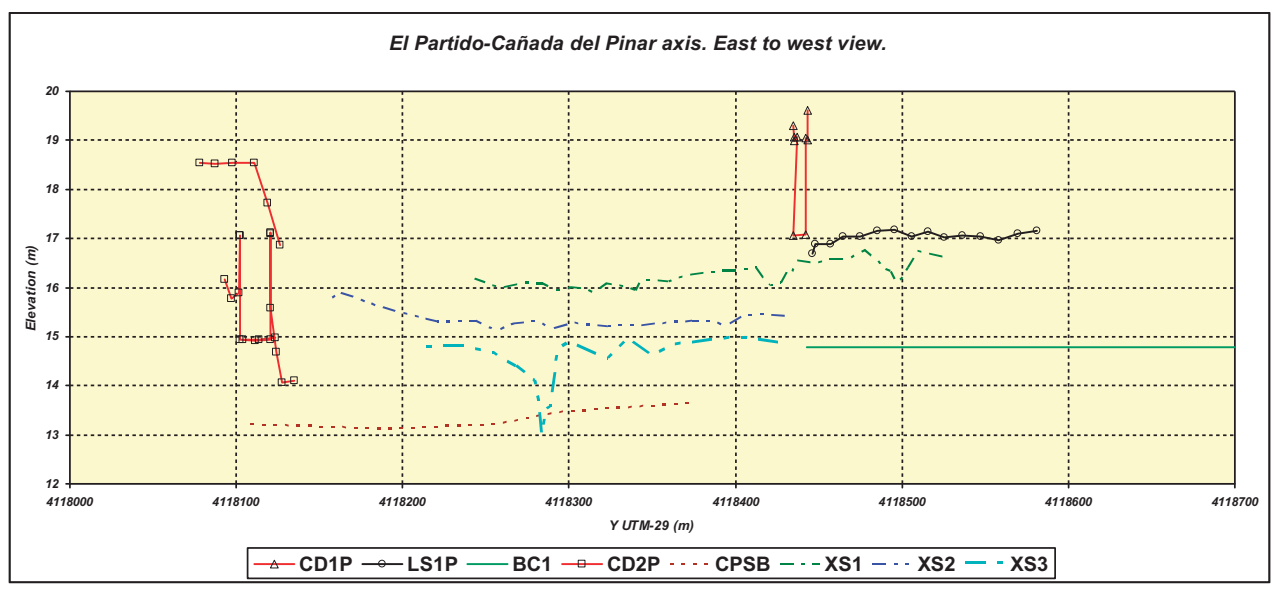

Figure 11: Elevation view (from east to west) of elements composing the FCS, and flood response on 1 and 5 February 2009. From left to right: CD2 profile (CD2P); Cañada del Pinar streambed profile (CPSB); cross-sections defined by floods in the flood-lamination-sedimentation area, surveyed on 6 June 2009 (XS1, XS2, $\mathrm{XS3}$ ); CD1 profile (CD1P); CD1 lateral spillway profile (LS1P); CD1 backwater curve $(\mathrm{BC} 1)$.

part of the flood-lamination-sedimentation area, being the only one that was flooded in the hydrological year 2009-10.

Regarding the effects of these two flood events downstream the FCS area, it was found that El Partido stream flowed without interruption by its current channel until the flooded marshes area in the DNP (from the Ford-Ajolí Bridge section, across the channel opened in the winter of 1997-98). Nevertheless, at the Ford-Ajolí Bridge section a part of the streamflow was derived to the Cañada Real road (a non-paved road crossing the Ajolí Bridge), although no sand was dragged and deposited and no damages were produced in El Rocío, as used to happen in the past.

\subsection{Behavior of the A3 in the hydrological year 2009-10}

From 20 December 2009 to 4 February 2010 six major flood events took place in El Partido stream that are summarized in Table 2. Before the first flood occurred all the weep holes in CD1 and CD2 were clogged up with concrete, except for the bottom drains. In this way, situations such as that occurred on 1 February 2009 were prevented. To estimate the flood hydrographs the same hydrological model previously exposed was adopted. However, for these events there were available accurate but non-continuous instant gauging data, which allowed for a first calibration of the model. Thereby the physical meaning of the results was improved. Table 3 shows the flow distribution through the different discharge elements at the $\mathrm{CD} 1$ during the period under review, obtained by the gauging of the water stages. These values were obtained in two different ways: a) by direct measurement of the water stage immediately upstream of the frontal spillway threshold of the CD1 (Direct) and b) measuring the same parameter calibrating sequential photographs (Photo) as shown in Fig. 12

We explain below the operations for HMS calibration for two flood events on 4 January 2010 and 4 February 2010. We present here only these two events (from the six analyzed), since they were the ones having a greater available dataset for calibration (Table 3). Figure 13 shows 
Table 2: Flood events of El Partido stream between 21 December 2009 and 4 February 2010.

\begin{tabular}{lllcc}
\hline Flood date & \multicolumn{2}{c}{$\begin{array}{c}\text { Start and end of rainfall events } \\
\text { (date and time }- \text { GMT) }\end{array}$} & $\begin{array}{c}\text { Accumulated } \\
\text { rain rate } \mathrm{P}(\mathrm{mm})\end{array}$ & $\begin{array}{c}\text { Flow rate } \mathrm{q}_{\mathrm{p}} \\
\left(\mathrm{m}^{3} \mathrm{~s}^{-1}\right)\end{array}$ \\
\hline 12/21/2009 & $20 / 12 / 0919: 00$ & $21 / 12 / 096: 00$ & 56.9 & 332 \\
$12 / 23 / 2009$ & $22 / 12 / 0923: 00$ & $23 / 12 / 097: 00$ & 43.7 & 347 \\
$12 / 28 / 2009$ & $28 / 12 / 092: 00$ & $28 / 12 / 0913: 00$ & 26.6 & 212 \\
$01 / 04 / 2010$ & $03 / 01 / 109: 00$ & $04 / 01 / 1011: 00$ & 62.4 & 292 \\
$01 / 14 / 2010$ & $13 / 01 / 1014: 00$ & $13 / 01 / 1020: 00$ & 12.9 & 122 \\
$02 / 04 / 2010$ & $03 / 02 / 1020: 00$ & $04 / 02 / 105: 00$ & 44.7 & 205 \\
\hline
\end{tabular}

Table 3: Flow rates discharging through the different spill sections of the FCS at the CD1 estimated with the head level of the frontal spillway threshold, obtained from direct measurement (Direct) or through calibrated photographs (Photo).

\begin{tabular}{|c|c|c|c|c|c|c|}
\hline \multirow[b]{2}{*}{ Date } & \multirow[b]{2}{*}{ Time } & \multirow[b]{2}{*}{$\begin{array}{l}\text { Flow rate } \\
\left(\mathrm{m}^{3} \cdot \mathrm{s}^{-1}\right)\end{array}$} & \multirow[b]{2}{*}{$\begin{array}{l}\text { Type of flow } \\
\text { measurement }\end{array}$} & \multicolumn{3}{|c|}{$\begin{array}{l}\text { Flow distribution through different } \\
\text { spill elements }\left(\mathrm{m}^{3} \cdot \mathrm{s}^{-1}\right)\end{array}$} \\
\hline & & & & $\begin{array}{l}\text { Frontal } \\
\text { spillway and } \\
\text { bottom drain }\end{array}$ & $\begin{array}{l}\text { Lateral } \\
\text { spillway }\end{array}$ & $\begin{array}{c}\text { Backwater } \\
\text { Cañada del } \\
\text { Pinar }\end{array}$ \\
\hline $12 / 21 / 2009$ & $13: 20$ & 95.2 & Photo & 13.0 & 75.2 & 7.0 \\
\hline $12 / 22 / 2009$ & $13: 22$ & 3.2 & Photo & 1.2 & 2.0 & 0.0 \\
\hline $12 / 24 / 2009$ & $13: 12$ & 37.7 & Photo & 6.4 & 31.3 & 0.0 \\
\hline 01/04/2010 & $12: 45$ & 234.9 & Photo & 27.5 & 174.5 & 32.9 \\
\hline $01 / 05 / 2010$ & $10: 30$ & 29.5 & Direct & 5.2 & 24.3 & 0.0 \\
\hline 01/05/2010 & $11: 05$ & 18.5 & Photo & 3.7 & 14.8 & 0.0 \\
\hline 01/14/2010 & $10: 00$ & 8.2 & Direct & 2.2 & 6.0 & 0.0 \\
\hline $01 / 14 / 2010$ & $12: 32$ & 4.9 & Photo & 1.6 & 3.3 & 0.0 \\
\hline $01 / 15 / 2010$ & $12: 32$ & 0.2 & Photo & 0.2 & 0.0 & 0.0 \\
\hline 02/04/2010 & $8: 00$ & 198.2 & Direct & 23.7 & 148.8 & 25.7 \\
\hline 02/04/2010 & $11: 00$ & 163.8 & Direct & 20.2 & 124.4 & 19.2 \\
\hline 02/04/2010 & $11: 56$ & 85.2 & Photo & 11.9 & 67.9 & 5.4 \\
\hline 02/04/2010 & $18: 41$ & 15.2 & Photo & 3.2 & 12.0 & 0.0 \\
\hline $02 / 04 / 2010$ & $18: 51$ & 9.5 & Direct & 2.4 & 7.1 & 0.0 \\
\hline $02 / 05 / 2010$ & $12: 45$ & 15.2 & Direct & 3.2 & 12.0 & 0.0 \\
\hline $02 / 05 / 2010$ & $13: 39$ & 9.5 & Photo & 2.4 & 7.1 & 0.0 \\
\hline
\end{tabular}

(in maroon) the rain rates recorded in Bollullos station and two simulations run with HECHMS model of the FCS flood flow (blue and green). The first simulation (blue) was performed using a reduction factor of 0.5 for the time of concentration $t_{c}$ (obtained with the USDA-SCS eqn (1)), while for the second simulation (green) a reduction factor of 0.75 was applied (simulations were performed under a set of different conditions, but were discarded because of a poor performance in calibration process, having no specific approach to available gauging data). 

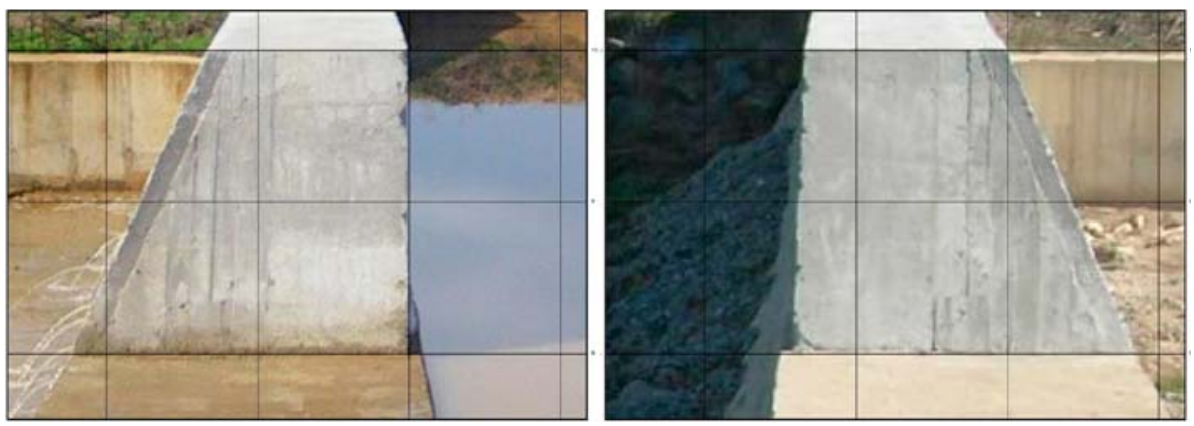

Figure 12: Photographs showing the inner walls of the frontal spillway of CD1, viewed from the left bank to the right bank (left) and seen from the right bank to left bank (right). Two squares fitted from the spill threshold to the crest can be seen. Each square side is $1 \mathrm{~m}$ long and over them is measured the water stage immediately upstream of the frontal spillway threshold.

Figure 13 shows, along with the simulated flow rates, the measured instant flow rates (the measurements made on calibrated photographs with red dots and the in situ direct measurements with yellow triangles). In this way the $\mathrm{CN}$ and $t_{c}$ were calibrated. The simulated peak flows displayed in Table 2 can credibly explain the effects caused by water and sediments flows at the different reaches of El Partido stream. Figure 14 displays photographically the behavior and the effects linked with the flood event on 4 January 2010 passing through the lateral spillway of the CD1 and the flood-lamination-sedimentation area. Figure 15 shows the situation at the CD1 as well, on 5 February 2010 after the flood event of the previous day.

\subsubsection{Behavior of the A3 in the hydrological year 2009-10 on the new alluvial fan of El Partido, outside El Rocío village}

In Section 4.4, we have analyzed the flood flows discharged by six flood events directly to El Partido stream through the CD1. Such flow rates run throughout El Partido channel to the FordAjolí Bridge section without exceeding the bank levels, with flow rates likely not much higher than $40 \mathrm{~m}^{3} \cdot \mathrm{s}^{-1}$ (in the light of the estimated hydrographs and theoretical stage-discharge curves).

From the Ford-Ajolí Bridge section and downstream, flood flows below $20 \mathrm{~m}^{3} \cdot \mathrm{s}^{-1}$ run downstream throughout the stream operating channel (since the winter of 1997-98), to drain at the flooded marsh area. Downstream this section the flood may have behaved at some reach as a sort of caño. But in flood events with flow rates greater than $20 \mathrm{~m}^{3} \cdot \mathrm{s}^{-1}$, approximately $20 \mathrm{~m}^{3} \cdot \mathrm{s}^{-1}$ continued downstream through the Ajolí channel (or even slightly higher flow rates due to the effect of higher water stages upstream the bridge), and the remaining flow was diverged to the Cañada Real road, as it was verified and quantified with a HEC-RAS version 3.4 simulation [9] (Fig. 16, image on the right).

Different simulation runs were performed for the six flood events analyzed and applied to a reach between a section immediately upstream the ford and a section immediately downstream the bridge (surveyed with a DGPS), since there was the certainty that the local topography will enforce a flow distribution between these two sections.

The flow distribution between El Partido channel and the Cañada Real at the Ford-Ajolí Bridge section was found in five of the six studied flood events. In these five cases the FCS flood flow exceeded $150 \mathrm{~m}^{3} \cdot \mathrm{s}^{-1}$, which implies a flow rate exceeding $20 \mathrm{~m}^{3} \cdot \mathrm{s}^{-1}$ running through El Partido channel downstream the CD1. Figure 16 shows the water stage, in a 


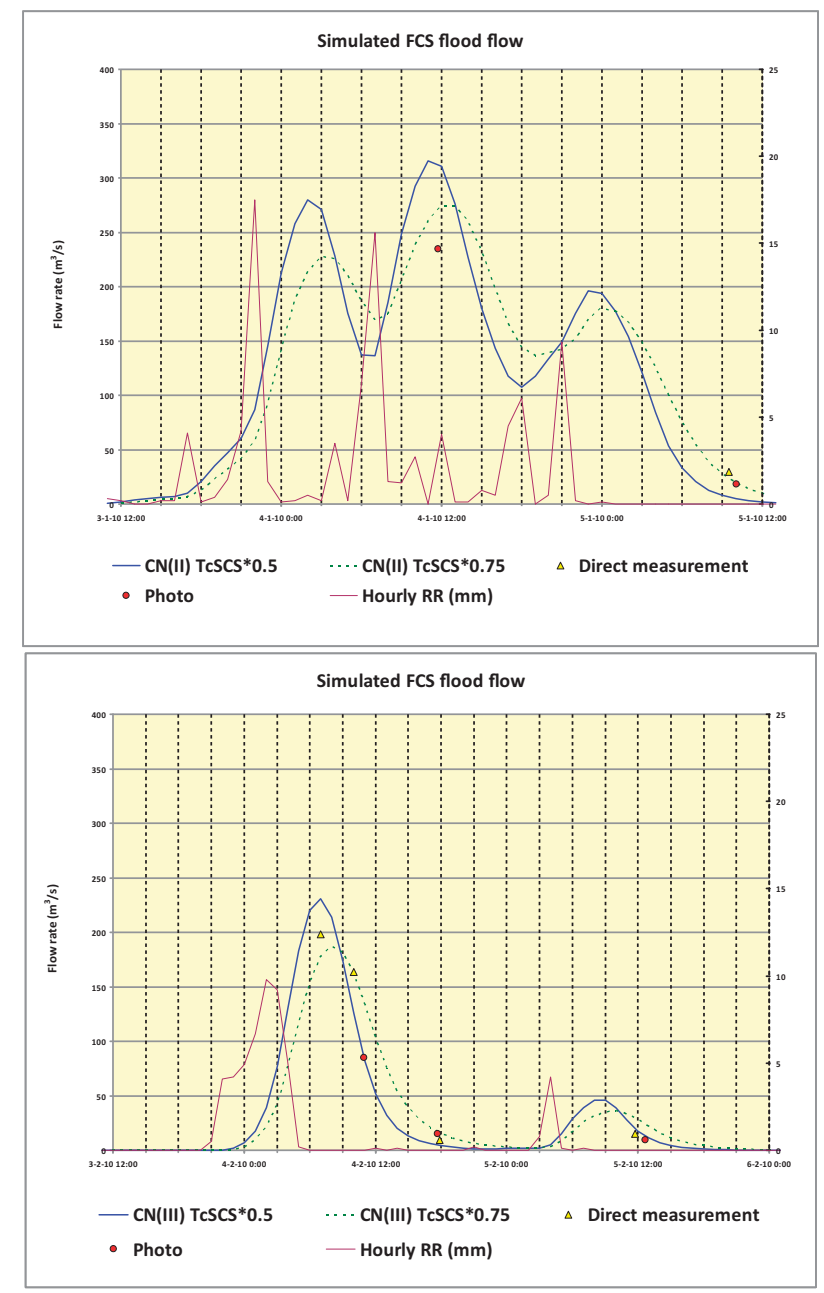

Figure 13: Rainfall rate ( $\mathrm{mm}$ ) measured in Bollullos station (maroon). Top: Flow rate $\left(\mathrm{m}^{3} \mathrm{~s}^{-1}\right)$ simulated by flood on 4 January 2010 with $\mathrm{CN}$ in condition II and $0.50 t_{c}$ (blue continue) or $0.75 t_{c}$ (green in dots). Bottom: Flow rate $\left(\mathrm{m}^{3} \mathrm{~s}^{-1}\right)$ simulated by flood on 4 February 2010 with $\mathrm{CN}$ in condition III and $0.50 t_{c}$ (blue continue) or $0.75 t_{c}$ (green in dots). Flow rate estimated by direct measurement (yellow triangles) and by calibrated photographs (red dots).

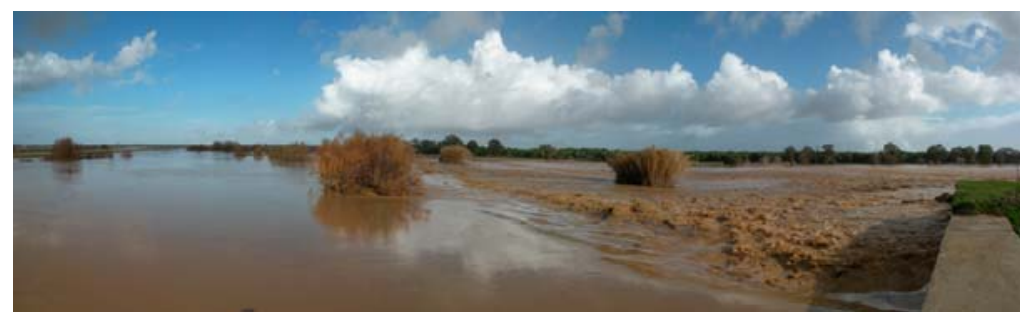

Figure 14: Discharge of the flood flow at 12:47 h (local time) on 4 January 2010 through the lateral spillway of CD1. 


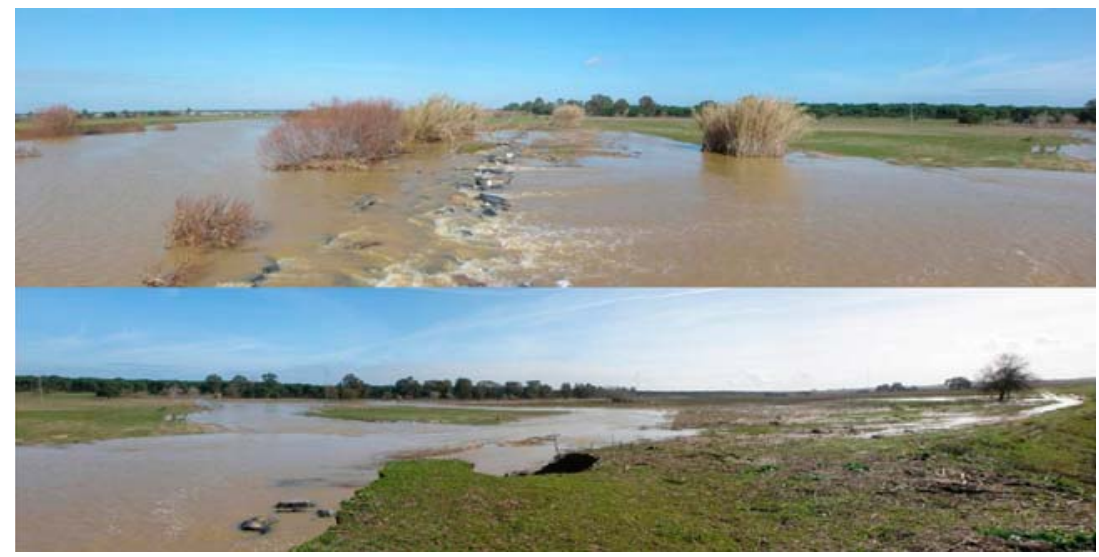

Figure 15: Upper image: Flood discharge at 13:41 h (local time) on 5 February 2010 (the day after the flood event) through the lateral spillway of CD1. Lower image: Effect of the flooding in the flood-lamination-sedimentation plain at 12:49 $\mathrm{h}$ (local time) on 5 February 2010.

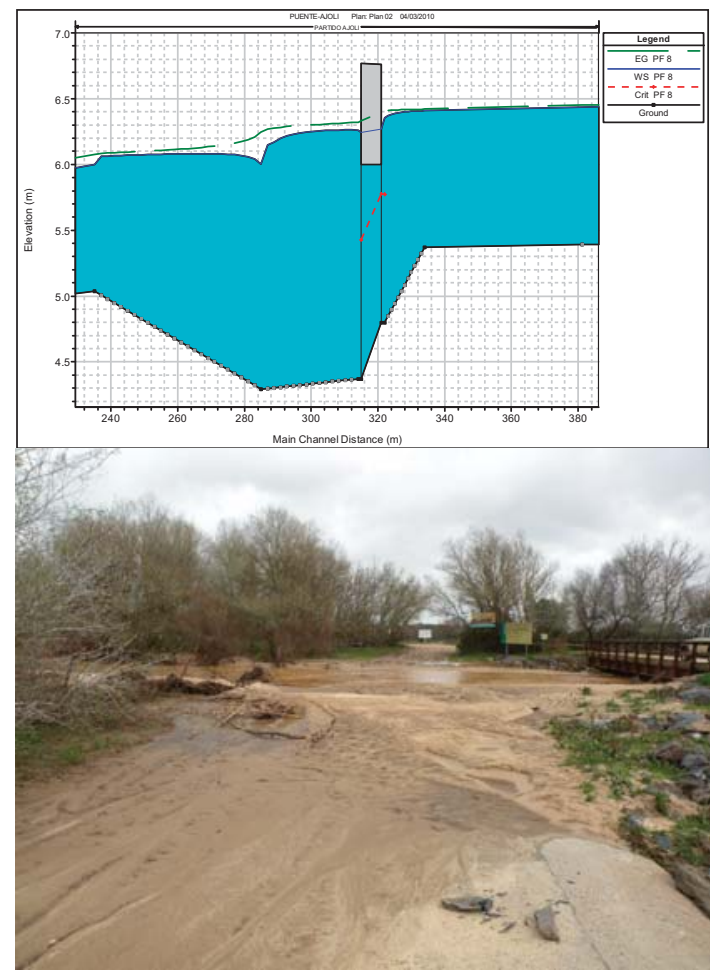

Figure 16: Upper image: Profile section plot output, resulted from HEC-RAS simulation, showing the streamflow through the reach between the Ford and the Ajolí Bridge sections for a flow rate of $20 \mathrm{~m}^{3} \mathrm{~s}^{-1}$, from which a part of the streamflow is diverted to the Cañada Real, following the local slope gradient. Lower image: View of the Ajolí Ford, in the center of the image, on 22 February 2010, on the right side the Ajolí Bridge; in the foreground the spot from where a part of flood flow is diverted to the Cañada Real. 
profile section plot, resulted from simulation with HEC-RAS model at the Ford-Ajolí Bridge section and a photograph of the section where the flood coming from El Partido is diverged to the Cañada Real road when the flow rate exceeds $20 \mathrm{~m}^{3} \cdot \mathrm{s}^{-1}$.

In summary, the six flood events that were analyzed presented the following behavior at the eastern area of El Rocío, downstream the Ford-Ajolí Bridge section:

a. While the FCS flood flow does not exceed $150 \mathrm{~m}^{3} \cdot \mathrm{s}^{-1}$, the direct stream discharge to the marsh is limited to $20 \mathrm{~m}^{3} \cdot \mathrm{s}^{-1}$, flowing through El Partido channel with no associated significant torrential phenomena (i.e. erosion, transport, and sedimentation). It can be said that the flow behaves as a proper motion flow into a channel until the Ford-Ajolí Bridge section and specifically as a caño downstream the mentioned section.

b. When the FCS flood flow exceeds $150 \mathrm{~m}^{3} \cdot \mathrm{s}^{-1}$, due to the hydraulic conditions occurring immediately upstream the Ford-Ajolí Bridge section, in which the topography and the self-bridge directly affect the flow behavior, a part of the flow is diverted to the Cañada Real road.

c. The flood flow diverted to the Cañada Real flowed through it following the slope gradient to meet the Caño Marin on the eastern side of the protective levee of El Rocío village. A part of the diverted flow returned to El Partido stream near to the marsh inlet, but another part remained in that area causing its flooding. However, it was not a matter of concern because the sand load of the flow was very low and therefore it could be discharged slowly toward the marsh.

d. The flood lasted over a month, but with varying degrees of intensity. The stored water was being concentrated at the lower elevation areas, according to the micro-topography of the study site producing a new drainage channel for this area. Figure 17 shows, in left image, a new drain formed on the plain at the eastern side of the protective embankment of El Rocío village, viewed from north to south, from the road connecting the pumping station of El Rocío; and in the right image the erosive effects caused by the new drain (solid red line) on an aerial photograph taken in 2008. The blue arrow points out the routing of the water toward the marsh. In this image, the road leading to the pumping station of El Rocío can be seen (with green dots).
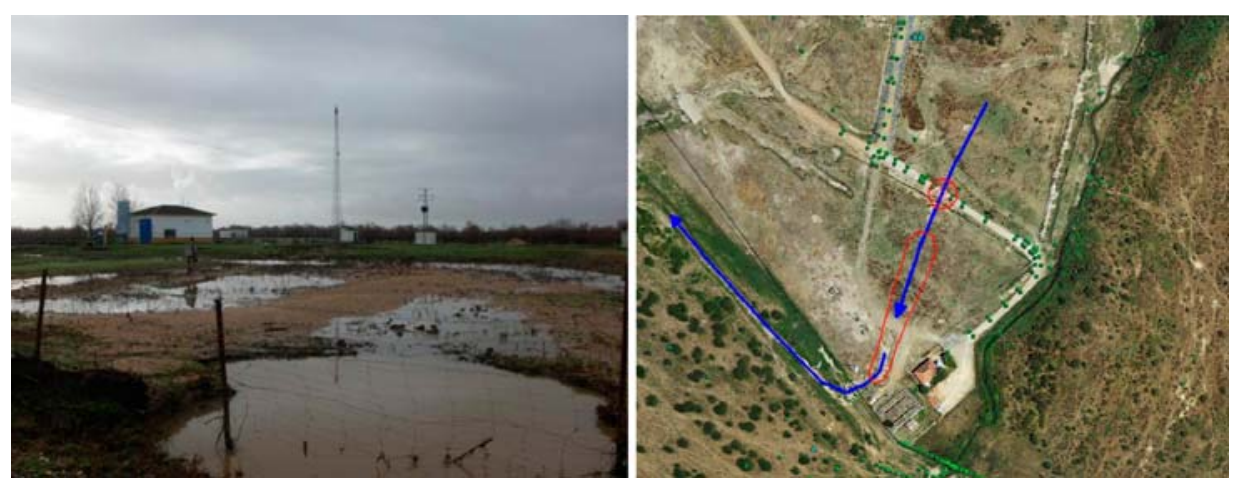

Figure 17: Left: New drain formed near the pumping station of El Rocío on 5 February 2010. Right: An aerial photograph taken in 2008 showing the routing (blue arrows) of the new drain formed on 5 February 2010. 
e. The advance of this new drainage of the flooded area was stopped by the road (which also acted as a small levee) connecting the pumping station of El Rocío (Fig. 17). A cause of warning is the fact that if this drainage is able to trigger retrogressive erosion processes linking this area with the current channel of El Partido, the stream channel (which is the axis of the sedimentation fan) would direct the main flow westward to the plain aside El Rocío and the new drainage. This fact may cause the activation of the alluvial fan, producing a new problem because the entire flow volume would be directed to the urbanized area of El Rocío, raising the flood level and creating difficulties for the drainage of this area close to the village. To avoid this problem, we recommended maintaining a sufficient and uniform elevation for the main levees that are arranged in the area (the levee that protects the main area of El Rocío, the extension of this levee toward the marsh, and the levee-road that joints the latter with the pumping station of El Rocío), though without creating further obstacles to the flood movement, because the more the water spreads out, the less it is able to transport the streambed sands.

We conclude this section with four images of El Partido stream downstream the Ajoli Bridge. Figure 18 shows four sequential stages in the evolution of the El Partido stream and the new alluvial fan formed at area, between 1996 and 2008. Upper images on the left show the former channel of El Partido stream after several flood events during the previous days (29 January 1996). The upper images on the right show the channel of El Partido stream completely silted after several major flood events during the previous months (21 March 1997). The lower images on the left show El Partido channel downstream the Ajolí Bridge in November 2002; this image is divided in two parts: on the left is the former channel and on the right is the current operating channel. The lower image on the right shows the evolution of a caño-type morphology of the new operating channel of the El Partido stream in July 2008.
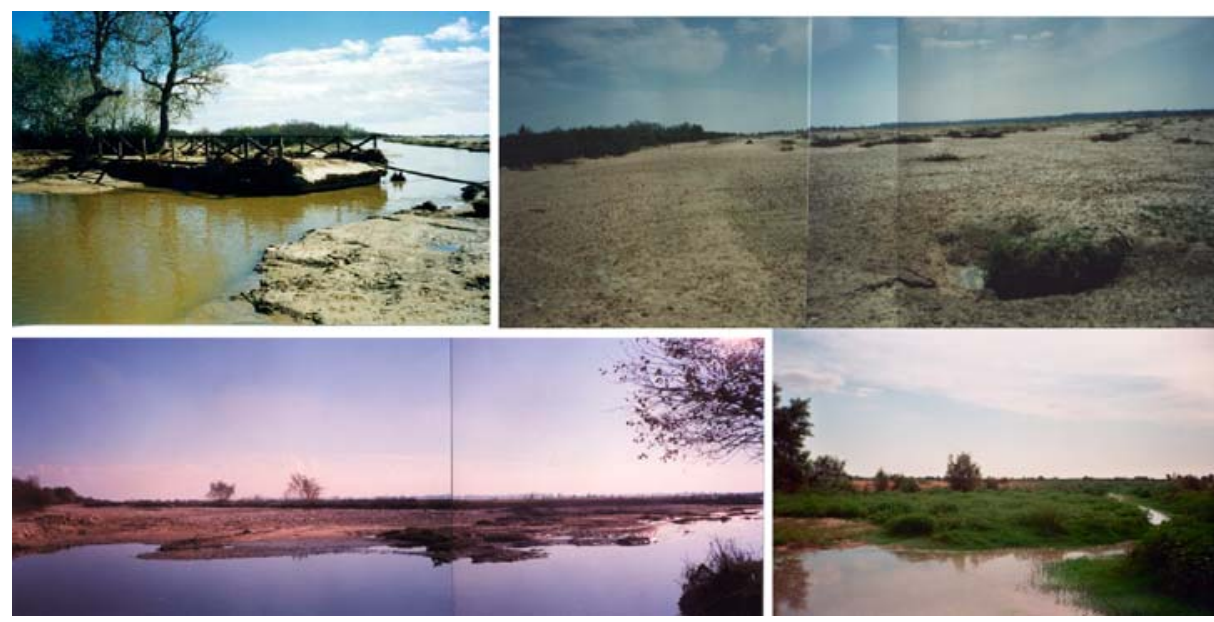

Figure 18: Evolution stages of the channel of El Partido stream and the new alluvial fan immediately downstream the Ajolí Bridge, between 1996 and 2008. Upper images: left: 29 January 1996; right: completely silted on 21 March 1997. Lower images: left: November 2002; right: July 2008. 
a. The first one, taken on 29 January 1996, shows the Ajolí Bridge after several major flood events, which dragged and deposited a great amount of sand to this place, and thus raising the streambed elevation and causing the fall of the bridge. In the image El Partido stream still flows through its primitive channel.

b. The second one, taken on 21 March 1997, shows the former streambed which completely disappeared by aggradation, after the major flood events occurred in the previous months. From this date the stream opened its new channel downstream the Ajolí Bridge section, following the local slope, which conditioned the westward direction (toward El Rocío village).

c. The third photograph (November 2002) shows the stream present in two different channels downstream the Ajolí Bridge; on the left of the image lies the former non-operating channel, due to aggradation, and on the right the channel opened westward in the winter of 1997-98, remaining active nowadays.

d. The last image, taken in early July 2008, shows both channels again and highlights the caño-type morphology acquired by the operating channel of El Partido stream in recent years, since the construction of the CD1.

In summary, the stream channel has evolved into a caño-type morphology, in a similar way as it was in the past when the area belonged to the marsh, but nowadays it lies over the sedimentary deposits produced during the period that lasted the channelization.

\section{SITE-SPECIFIC CONCLUSIONS}

1. In the monitoring of the A3 of the Doñana 2005 Project it was intended since 2006: a) to analyze the A3 evolution, b) to correct the deviations from the project objectives, especially regarding the most vulnerable areas, such as the eastern side of El Rocío village, c) to foresee the future impacts. The monitoring is justified because, as El Partido stream presents a torrential pattern, the actions undertaken on it and its environment should be adjusted to the water and sediments flow dynamics determined by the major flood events have a strong impact in the area.

2. The main objective of the A3 is to avoid floods and/or sedimentation processes in the eastern side of El Rocío village, as a result of the upgrade of the new alluvial fan formed on the DNP marshes. Since the stability of the alluvial fan depends mainly on the recovery of the former (before 1981) hydraulic and hydrological regime, the A3 raised and executed a project to meet this objective.

3. The project involved the construction of the CD1, placed at El Partido stream, and the CD2, located at the Cañada del Pinar stream, and devoted an area between both streams with flooding, lamination, and sedimentation purposes. With this scheme following objectives have been achieved: a) establishing a FCS for El Partido stream, b) rehabilitating the Cañada del Pinar stream as a drainage channel for the flood events that El Partido stream suffers, c) setting back the sedimentation processes of El Partido toward the places where it used to occur in the past, d) canceling the effect of lengthening of the stream gorge caused by the channelization; and as a result of all of them, e) redirecting the evolution of El Partido stream to a caño-type morphology, as it was in the past over the marsh, but this time settled on the new alluvial fan formed over the marsh. The caño-type morphology was also the natural configuration of the stream over the former alluvial fan, therefore, the new configuration can be interpreted as the first step in stabilization of the new alluvial fan. 
4. The flood flow distribution at the CD1 between the frontal and lateral spillways, after the corrections made in 2009 , has led to a significant reduction of the flow rates getting to the Ford-Ajolí Bridge section. Even for the largest flood rates, a massive drag of sands has been prevented, and thereby preventing the growth of the new alluvial fan over the marsh. Given the local slope toward the urbanized area of El Rocío, if the fan grew, it would adopt this same direction and thus the inhibition of this growth helps to maintain the local relief and save the current drain possibilities of the urbanized area of El Rocío.

5. The specific topographical conditions of the Ford-Ajolí Bridge section enforce the flow split between the stream channel and the Cañada Mayor road for flow rates above $20 \mathrm{~m}^{3} \cdot \mathrm{s}^{-1}$. If the topographical conditions of this section were different, e.g., if they had a more open configuration, probably El Partido streambed would follow an adaptation to a caño-type morphology upstream the Ajolí ford, reaching eventually the section located immediately downstream the stilling basin of CD1. This would involve a retrogressive effect of sediments deposition in the channel; but this is not possible, due to both the narrowing of the Ajolí Bridge section, and the remaining effects of the former stream channelization upstream the mentioned section.

6. As we explained a part of the flood flow running through El Partido stream is diverted to the Cañada Mayor road, which is collected by the Caño Marín, and from that point comes into the plain aside the protective embankment of El Rocío village. This area is drained as well by El Partido stream to the flooded area of the marsh. But if the water stage in the plain is too high, the stream is not able to evacuate all the stored water volume and the area remains flooded. Initially, this is not major problem, because the sand load getting to this point is minimal since the relevant adjustments on CD1 were accomplished. Therefore, the flood can be drained slowly to the marsh. But if the flooding persists, the water is concentrated at the lower elevations of the plain and new drains may be produced to the marsh.

7. If these drains are isolated their effect is limited. However, if a retrogressive erosion process is triggered linking the drain with El Partido channel, the stream (which is the axis of the alluvial fan) would be addressed to the new drain westward, destabilizing the alluvial fan and leading the entire flow volume to the west of the urbanized area of El Rocío. This new situation may cause a rise in flood stage, hindering the drain of the flooded area. In order to avoid this problem, we recommend maintaining a sufficient and uniform elevation of the main protective embankments that are arranged in the area (the levee that protects the main area of El Rocío, the extension of this levee toward the marsh, and the levee-road that joints the latter with the pumping station of El Rocío), though without creating further obstacles to the flood movement, because the more the water spreads out, the less it is able to transport the streambed sands.

8. The adoption of the previous measure is complementary to the reduction of flood flows reaching the marshes of El Rocío through El Partido stream; this is the priority and contributes to behavior pattern resembling the one that the stream had in the past before the channelization.

9. The reduction of El Partido streamflow reaching the marshes of El Rocío, by means of diverting the greater part of them toward the Cañada del Pinar stream and from there to the Caño Mayor stream (Fig. 1), means a return to the operation system of the sedimentaryhydrologic system of the study area before the channelization in 1981, supported by both the site geomorphology and the continuity equation. The Cañada del Pinar stream has 
performed as drainage of the water stored in the flood-lamination-sedimentation plain devoted under the A3, without causing problems related to flow and sediments phenomena in the flood events on 1 and 5 February 2009, and in the six major flood events in 2009-10 analyzed in this paper. Obviously, these flood events caused the flooding of the lower elevation sites of both streams and deepened the existing pools. But in a field survey in July 2010 along the Cañada del Pinar stream to the joint with the Caño Mayor stream, and thence to the mouth in the DNP marshes (in a different location far from El Rocío), no significant drags or deposits of sand were detected. The most plausible explanation is that both the Cañada del Pinar and Caño Mayor streams maintained their main original morphologic features through the years, being able to expand the flood flow across both overbanks.

\section{CONCLUDING REMARKS}

The floods of El Partido presented a very aggressive behavior in the period 1981-2006, when the $7 \mathrm{~km}$ of channelization before the NDP marshes were fully operative, due to the torrential characteristics of the stream regime. In major flood events, an increase of the regular streamflow $\left(1.0 \mathrm{~m}^{3} \cdot \mathrm{s}^{-1}\right)$ by two hundred times, was likely and even more. Moreover, flood flows were constrained into the channel walls, which caused the degradation of the streambed, carrying the eroded material to the El Rocio marshes, producing there a new alluvial fan. This process has been widely investigated, tested, and diffused $[1,2,4,13,14,15,16]$.

The research hereby focused exclusively on the monitoring of the restoration project of the original alluvial fan of El Partido. This monitoring was centered on the behavioral analysis of the restoring works in a series of major rainfall events that occurred between 1 February 2009 and 2 April 2010. Previously, the monitoring was limited to quantify the effects caused by floods in the neighborhood of El Rocío. The analysis carried out in this study was raised after obtaining a first approach of the severity of such effects, concluding that the works required certain adjustments to adequately design the torrential regime of the stream. It is therefore a research with a marked finalist character in order to establish the guidelines to protect the eastern area of El Rocío village in flood events. The results hereby presented, enable the definition of the extent of water and sediments phenomena that may affect the nearby area, according to different flood intensities. However, more general conclusions may be asserted:

a. It has to be noted that the torrential character of a stream not only depends on the selfstream slope, but more decisively on the streamflow dynamics regarding the flow oscillations that can occur in short time intervals. In the case of El Partido stream, when Atlantic storms fall on its watershed, its streamflow may exceed by two hundred times the regular hydrological module, despite its low slope and the gentle relief of the catchment area. Thus, this stream is not a proper torrential stream, but a stream presenting a torrential regime.

b. Periodic site topographical surveys may be needed to detect morphological site modifications over time. The gentler the relief and the less cohesive the soils, more necessary the operation is. In the case of El Partido stream (the topography is very smooth and soils profiles are mainly sandy), successive site topographic leveling shed light on the new alluvial fan evolution and how to deal with its stabilization.

c. It is inadequate to consider that a torrential stream is corrected when the hydraulic correction project is undertaken, but after a monitoring process able to check that the works and dispositions undertaken with the project fit with the torrential dynamics of the stream. 


\section{ACKNOWLEDGMENTS}

We thank the Scientific Committee of the Doñana 2005 Project and the Doñana Natural Area of the Protected Natural Areas Network of Andalusia (RENPA), for their research projects funding support that permitted our knowledge of the situation, which was essential to write this document. We especially acknowledge the Engineer Director of the works of the Action no. 3, Benigno Bayan Jardín, the Technical Assistant of the Conservation Area of the DNP, Carlos Urdiales Alonso and his assistants Abel Valero Lancho and Diego García Díaz, as well as the professor of the UPM Juan Ignacio García Viñas who worked with us on field works. The photographs in Figs. 10 and 14, the one on the left in Fig. 5, and on the right in Figs. 9 and 16 have been released by the referred team of the Conservation Area of the DNP.

\section{REFERENCES}

[1] Sendra Arce, P.J., Investigación cuantitativa del transporte de sedimentos no cohesivos en avenidas torrenciales: Aplicación al caso del arroyo del Partido, Huelva. Tesis Doctoral, Departamento de Ingeniería Forestal, Escuela T. S. Ingenieros de Montes: Universidad Politécnica de Madrid, pp. 400, 2002.

[2] Mintegui, J.A., Robredo, J.C. \& Sendra, P.J., Avenidas torrenciales en el arroyo del Partido y su incidencia en la marisma del Parque Nacional de Doñana, Naturaleza y Parques Nacionales, Serie Técnica, Organismo Autónomo Parques Nacionales: Madrid, pp. 373, 2003.

[3] Mao, L., Analisi comparativa del transporto solido di corsi torrentizi in diversi ambiti geografici Ph Thesis. Dipartimento Territorio e Sistema Agro-Forestali: Università degli Studi di Padova, pp. 307, 2005.

[4] Mintegui, J.A., Lenzi, M.A., Robredo, J.C. \& Mao, L., Movilización versus estabilización de los sedimentos en cursos sometidos a la dinámica torrencial, Naturaleza y Parques Nacionales, Serie Técnica, Organismo Autónomo Parques Nacionales: Madrid, pp. 143, 2006.

[5] Mintegui, J.A., Robredo, J.C., Gonzalo, C. de \& Huelin, P., Seguimiento de la Actuación núm. 3 del Proyecto Doñana 2005, E. T. S. de Ingenieros de Montes, Departamento Ingeniería Forestal: Universidad Politécnica de Madrid, pp. 139, 2009.

[6] Mintegui, J.A., Robredo, J.C., Mao, L. \& Lenzi, M.A., Formation, expansion and restoration of a sedimentation fan: the case of the Arroyo del Partido stream (Spain). Monitoring, Simulation, Prevention and Remediation of Dense Debris Flows III, eds D. de Wrachien \& C.A. Brebbia, WIT Transactions on Engineering Sciences, 67, pp. 249-259, 2010 b. doi:10.2495/DEB100211

[7] Saura, J., Bayán, B., Casas, J., Ruiz de Larramendi, A. \& Urdiales, C., Documento marco para el desarrollo del Proyecto Doñana 2005, Regeneración hídrica de las cuencas y cauces vertientes a las marismas del Parque Nacional de Doñana, Ministerio de Medio Ambiente, pp. 201, 2001.

[8] U. S. Army Corps of Engineers, Hydrologic Engineering Center. HEC-HMS (Hydrologic Modelling System), Version 3.4, 2009.

[9] U. S. Army Corps of Engineer, Hydrologic Engineering Center. HEC-RAS (River Analysis System), Version 4.0, 2008.

[10] Robredo, J.C., Mintegui, J.A., Gonzalo, C. \& de Huelin, P., Ampliación, seguimiento y actualización del modelo sedimentario de la marisma del Parque Nacional de Doñana, 6 Anexos, E. T. S. de Ingenieros de Montes, Departamento Ingeniería Forestal, Universidad Politécnica de Madrid; Espacio Natural de Doñana, Consejería de Medio Ambiente, Junta de Andalucía, p. 227, 2010. 
[11] Urdiales, C. Informe Cambios recientes en el tramo final del arroyo del Partido, Parque Nacional de Doñana, Organismo Autónomo Parques Nacionales, Ministerio de Medio Ambiente, 1996.

[12] García Nájera, J.M., Principios de Hidráulica Torrencial y su Aplicación a la Corrección de Torrentes. Instituto Forestal de Investigaciones y Experiencias: Madrid, pp. 297, 1943.

[13] Mintegui Aguirre, J.A. \& Robredo Sánchez, J.C., Formación del cono de sedimentación de en curso torrencial. - Análisis del arroyo del Partido (Huelva). Libro Homenaje a Don Ángel Ramos Fernández, eds Real Academia Española de Ciencias Exactas, Físicas y Naturales; Academia de Ingeniería de España y Escuela Técnica Superior de Ingenieros de Montes, UPM, pp. 1555-1567, 1999.

[14] Mintegui, J.A., Robredo, J.C. \& Sendra, P.J., Development of sedimentation into the northen wetland of the Doñana National Park (Spain), IAHR-UPM Congress, Proceedings of Fifth International Symposium on Eco-hydraulics, September 12-17, 2004, Aquatic Habitat: Analysis \& Restoration: Madrid (Spain), Vol. 1, pp. 274-280, 2004.

[15] Mintegui Aguirre, J.A., Robredo Sánchez, J.C., Huelin Rueda, P. \& de Gonzalo Aranoa, C., Análisis de la adecuación de las acciones restauradoras efectuadas en el cono de sedimentación de un curso torrencial, ante la incidencia en el mismo de eventos extraordinarios durante el invierno de 2009-10, Aqua-LAC, 2(2), pp. 62-77, 2010c.

[16] Mintegui, J.A., Robredo, J.C., de Gonzalo, C. \& Huelin, P., Restoration of a degraded torrential stream by means of a flood control system: the case of Arroyo del Partido stream (Spain). Monitoring, Simulation, Prevention and Remediation of Dense Debris Flows III, eds D. de Wrachien \& C.A. Brebbia, WIT Transactions on Engineering Sciences, 67, pp. 213-223, 2010a. doi:10.2495/DEB100181 